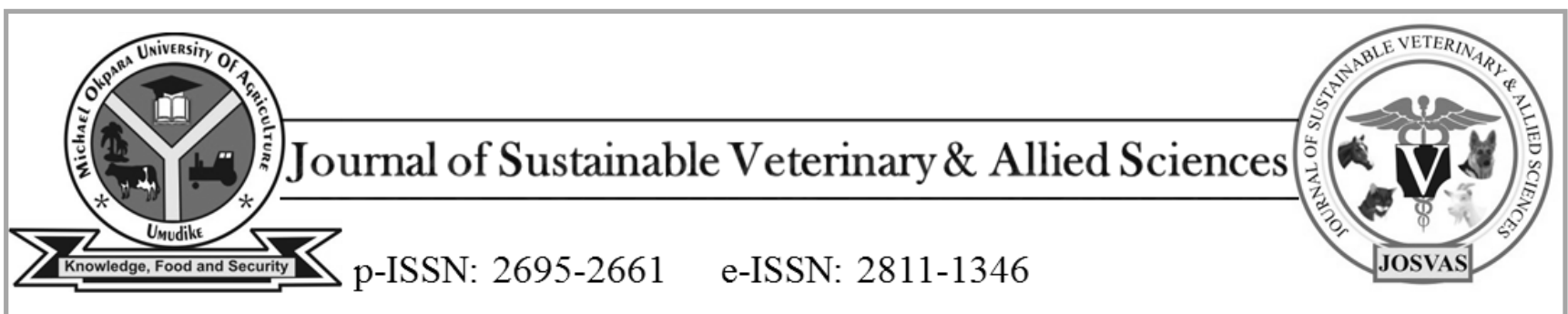

JoSVAS 2021, Vol 1, Issue 1: 62-66

C2021 College of Veterinary Medicine,

Michael Okpara University of Agriculture, Umudike, Nigeria

Original Research Article

\title{
Demographic study of dogs in rural and urban areas in Umuahia, Nigeria; a step towards eradication of rabies
}

*Nwoha R.O. \& Nwaogu, C.

Department of Veterinary Medicine, Michael Okpara University of Agriculture, Umudike, Nigeria.

*Corresponding author: rosemarynwoha@yahoo.com, +2348030987115

\begin{abstract}
Dog-mediated human rabies remains a major public health threat in Nigeria. The availability of reliable dog population estimates is the key in planning control strategies for canine rabies in developing countries. This study was conducted to evaluate the demography of dogs in Umuahia, Abia State, Nigeria. A cross sectional study was carried out in Umuahia North and Umuahia south, Local Government areas (LGA) Abia state, Nigeria, between September and November 2019. A total of 132 compounds in Umuahia North and 186 compounds in Umuahia South were randomly selected for administration of questionnaires. A total of 159 questionnaires were distributed for compound dog count. Information obtained included household information such as numbers of dogs in the premises, housing and control of dog movement. Others were history of dog bites and individual dog information such as breed, sex, age, source of dog, source of food and vaccination status. Two hundred and fifty-seven (257) dogs were counted which comprised 126 (49\%) males and 131 (51\%) females. Also, 46.3\% of the dogs were confined. The dog vaccination coverage in the dog population surveyed was 47.9\%. Majority of the respondents $(83.3 \%)$ stated that no member of their family has been bitten by a dog. The findings of this study show female: male ratio of dog to be 1.04:1. There was negligent dog ownership as a good number of dogs were left to roam. There was a low anti-rabies vaccination coverage in Umuahia North and Umuahia South LGAs which falls below recommendation of 70$80 \%$ vaccination coverage by the World Health Organization to achieve herd immunity.
\end{abstract}

.Keywords: Demography, dog, Nigeria, rabies, Umuahia.

\section{INTRODUCTION}

The science of population studies is known as demography or population demographics (Tarsi \& Tuff, 2012). Demography is the science that encompasses all the factors about population that include its number and characteristics (Tarsi \& Tuff, 2012). Demographic studies cover five basic topics that include the size of a population, its distribution across geographic areas, its composition (age, sex, race and other characteristics), changes in population size, distribution and composition over time and the determinants as well as consequences of population growth (Baker et al., 2017). The importance of demography lies in its contribution to helping government and society better prepare to deal with the issues and demands of population growth (Leeson, 2011).

The dog population in Nigeria is estimated to be between two and five million (Oboegbulem \& Nwakanobi, 1989; Otolorin et al., 2014). Dogs are found in both the rural and urban areas in undefined population of owned and stray dogs (Oboegbulem \& Nwakanobi, 1989). Dogs are the principal reservoirs host of rabies in Africa (Cleaveland et al., 2006) and Nigeria (Garba et al., 2006). Rabies has been associated with animal bites for more than 3000 years and it is the oldest ever known disease to the world of science (Atuman et al., 2014). Transmission is principally by dog bite from an infected animal especially dogs in Africa (NPC, 2006). Recent dog ecological study revealed that there is an increase in dog population established by presence of high density of dogs in urban areas in the country (Otolorin et al., 2014). Inadequate control of rabies in animals most importantly in dogs makes it easy for overrun to humans. The objective of the present study is to determine the demography of dogs in Umuahia South and Umuahia North LGAs. 


\section{MATERIALS AND METHOD}

A cross sectional study was carried out to evaluate dog demography in Umuahia, Abia State between September and November 2019 in Umuahia North and Umuahia South (LGA). A hundred and fifty-nine (159) questionnaires were used to determine the population of dogs in Umuahia North and Umuahia South (LGA) of Abia state. The questionnaires comprised of three sections. Section A involved the respondent information. Section B captured the dog's information and section $\mathrm{C}$ highlighted household information of dogs.

Umuahia North comprises of 21 communities while Umuahia South comprises of 29 communities. A total of 16 communities were surveyed in Umuahia South and 66 respondents were interviewed. Twelve (12) communities were also surveyed in Umuahia North and 93 respondents were interviewed.

\section{STUDY AREA}

The study was carried out in Umuahia North and Umuahia South (LGAs) of Abia state, Nigeria. Umuahia lies on longitude $7^{\circ} 29^{\prime} \mathrm{E}$, Latitude $5^{\circ} 321 \mathrm{~N}$ in the geographical map of Nigeria. Umuahia has a total population of 359,230 people as at the 2006 census (NPC, 2006). Umuahia town is traditionally owned by Ibeku after the British administration based the town in their lands. Towns bordering it are Aba, Okigwe, Abiriba, Ohafia and Owerri. The major languages spoken are Igbo and English. The major occupations of residents of Umuahia are civil service and trading.

\section{COMPOUND QUESTIONNAIRE SURVEY OF DOGS}

A well-structured compound questionnaire was designed and administered to 159 dog owners between September and November, 2019. A questionnaire was issued to an adult in each of the selected compounds. The adults were interviewed along the items on the questionnaire. Information obtained included household information such as numbers of dogs in the premises, housing and control of dog movement, and history of dog bites and individual dog information such as breed, sex, age, source of dog, source of food, and vaccination status. Houses without dogs or houses that refused to participate in the compound questionnaire survey were skipped for the next house possessing $\operatorname{dog}(\mathrm{s})$.

\section{DATA ANALYSIS}

Data generated was analyzed using the statistical packages for social sciences (SPSS) Version 20.0. Results obtained were presented as frequency and percentage using tables and charts. Student t-test was used where necessary to compare two groups. Values of $\mathrm{P} \leq 0.05$ were considered significant.

\section{RESULTS}

A total of 159 questionnaires were shared among dog owners in Umuahia North and Umuahia South LGAs and a total of 257 dogs were counted within the local governments. History of dog bite in each household was also obtained. Of the 257 dogs counted, 126 (49\%) were males and 131 (51\%) were females. One hundred and thirty nine $(57.1 \%)$ were mongrels, 64 (24.9\%) were cross breeds and 54 (21\%) were exotic breeds. One hundred and twenty-two $122(47.9 \%)$ were vaccinated while $135(52.5 \%)$ were unvaccinated. Forty one (41) that represented $15.95 \%$ of the counted dogs were puppies while $216(84.05 \%)$ were adults. One hundred and thirty eight (138) representing $53.7 \%$ were left to stray while $119(46.3 \%)$ were housed and never allowed to leave the premises. Out of the 159 respondents, 116 respondents $(83.3 \%)$ said that no member of their household has been bitten by a dog while 43 respondents $(16.7 \%)$ said a member

\begin{tabular}{|c|c|c|}
\hline $\begin{array}{c}\text { DEMOGRAPHIC } \\
\text { CHARACTERISTICS } \\
\end{array}$ & $\begin{array}{c}\text { FREQUENCY } \\
(\mathbf{F})\end{array}$ & $\begin{array}{c}\text { PERCENTAGE } \\
(\%)\end{array}$ \\
\hline \multicolumn{3}{|l|}{ SEX } \\
\hline MALE & 126 & 49 \\
\hline FEMALE & 131 & 51 \\
\hline TOTAL & 257 & 100 \\
\hline \multicolumn{3}{|l|}{$\begin{array}{l}\text { VACCINATION } \\
\text { STATUS }\end{array}$} \\
\hline VACCINATED & 122 & 47.5 \\
\hline JNVACCINATED & 135 & 52.5 \\
\hline TOTAL & 257 & 100 \\
\hline
\end{tabular}

CONTROL OF DOG
MOVEMENT

STRAY

138

53.7

HOUSED

119

52.5

TOTAL

257

100

AGE

PUPPIES

41

15.95

ADULT

216

84.15

TOTAL

257

100

\section{PREVALENCE OF}

DOG BITE

YES

\begin{tabular}{cc}
43 & 16.7 \\
214 & 83.3 \\
257 & 100 \\
\hline
\end{tabular}

TOTAL 257 100

\section{BREEDS}

LOCAL

139

57.1

CROSS

64

24.9

EXOTIC

54

21

TOTAL
257 
of their household has been bitten by a dog. Total number of dogs counted in Umuahia North was 143 while 114 dogs were counted in Umuahia South.

In Table II, the mean $(2.00 \pm 0.48)$ of unvaccinated dogs was slightly higher compared to the mean $(1.76 \pm 0.48)$ of vaccinated dogs. There was no significant difference between vaccinated dogs and unvaccinated dogs $(\mathrm{P}>0.05)$.

In Table III, The mean $(1.75 \pm 0.15)$ of stray dogs was higher than the mean $(1.49 \pm 0.89)$ of housed dogs. There was no significant difference between stray dogs and housed dogs ( $\mathrm{P}$ $>0.05)$.

\section{Table II: Mean \pm SE of vaccinated and unvaccinated dogs in Umuahia North and Umuahia South L.G.A, Abia state.}

\begin{tabular}{ccc} 
Vaccinated & Unvaccinated & Level of significance \\
\hline $1.76 \pm 0.16^{\mathrm{a}}$ & $2.00 \pm 0.48^{\mathrm{a}}$ & No significant difference \\
& $(\mathrm{p}>0.05)$
\end{tabular}

Table III: Mean \pm SE of stray and housed dogs within Umuahia North and Umuahia South L.G.A, Abia state

Stray Dogs Housed Dogs Level of significance

$1.75 \pm 0.15^{\mathrm{a}} \quad 1.49 \pm 0.89^{\mathrm{a}} \quad$ No significant difference $(\mathrm{P}>0.05)$

Table IV: Frequency of demographic characteristics of dogs in Umuahia North LGA, Abia state

\begin{tabular}{lccc}
\hline Characteristic & Number & Characteristic & Number \\
\hline Male & 57 & Female & 86 \\
Vaccinated & 93 & Unvaccinated & 50 \\
Stray & 82 & Housed & 61 \\
Puppies & 28 & Adult & 115 \\
\hline
\end{tabular}

Table V: Frequency of demographic characteristics of dogs in Umuahia South LGA, Abia state.

\begin{tabular}{lccc}
\hline Characteristic & Number & Characteristic & Number \\
\hline Male & 69 & Female & 45 \\
Vaccinated & 93 & Unvaccinated & 85 \\
Stray & 29 & Housed & 15 \\
Puppies & 99 & Adult & 101 \\
\hline
\end{tabular}

In Table IV above, there were 57 males and 86 females; 93 vaccinated and 50 unvaccinated dogs; 82 stray and 61 housed dogs; 28 puppies and 115 adults all recorded in Umuahia South LGA, Abia State.

There were 69 male and 45 female dogs; 29 vaccinated and 85 unvaccinated dogs; 99 stray and 15 housed dogs; 13 puppies and 101 adults recorded in Umuahia South LGA, Abia State (Table VI).

Out of 159 respondents, 43 persons said a member of their family has been bitten by a dog before while 116 persons said that no member of their family has been bitten by a dog. The incidence rate of dog bite cases was recorded as $27.04 \%$.

\section{DISCUSSION}

A total of 257 dogs were sampled within the rural areas in Umuahia North and Umuahia South LGAs, Abia state. The anti-rabies vaccination coverage was $47.9 \%$ which fell below the World Health Organization recommendation. The World Health Organization recommended an anti-rabies coverage of $70-80 \%$ in a dog population in an area in order to boost herd immunity (WHO, 2004). Fekadu (1991) suggested vaccination coverage of at least $80 \%$ in areas where stray and ownerless stray dogs predominate in order to terminate transmission of rabies. He also noted that if the vaccination coverage was not maintained, a sufficient susceptible population would rebuild and rabies would be rapidly reestablished.

The result of the vaccination status gotten from this study corresponds to that done in Aba, Abia state (Otolorin et al., 2014). The vaccination rate can be improved by creating more awareness about rabies and emphasizing the importance of vaccination. Also, the government should provide more veterinary stations for vaccination of dogs and report of dog bite cases. There was no significant difference $(\mathrm{P}<0.05)$ between the vaccinated and the unvaccinated dogs (Table II).

From the study, it was observed that a good number of dogs $(53.7 \%)$ were not confined. The presence of relatively higher number of stray dogs is of great public health concern as they form wild packs which aid the transmission of zoonotic diseases from companion animals (FAO, 2014). The high level of free roaming dogs brings about an increase in dog to dog or dog to human contact rates, thereby increasing the intensity of transmission and spread of rabies and other diseases (Hambolu et al., 2014). They may also serve as a source of environmental contamination for zoonotic helminth parasites as well as public health threat through physical injuries to humans through dog bites (Hambolu et al., 2014). A Dog bite may be malicious or be a result of defensive aggression such as protection of territory and resources including resting places, off springs and food (Atuman et al., 2014). The reasons for the increasing number of stray dog population include inability of the owners to provide food and shelter for the dogs probably due to high level of poverty among the general populace and ignorance 
of basic responsibilities of dog owners (Ogunkoya et al., 2012). Furthermore, the Nigerian cultural belief and communal attitude make it easy for dogs to stray from one house to the other. There was no significant difference $(\mathrm{P}<$ $0.05)$ between the confined dogs and stray dogs (Table III).

The WHO (1980) stated that the total number of 100 males per 100 females is called sex ratio, and it is recommended to be 100 males to 100 females that is $1: 1$ at birth. However, the present study demonstrated a sex ratio that skewed towards female dogs (male: female ratio $=1: 1.04$ ) that is female dogs (131) are more prevalent than male dogs (126) in Umuahia (Table I). This finding is in agreement with the findings of (Oboegbulem \& Nwakanobi, 1989) where male to female ratio is 0.8: 1 and Hambolu et al. (2014) where male: female ratio is $1: 1.5$. However, this contradicts the findings in other parts of Abia state (Otolorin et al., 2014) where male: female ratio is 1.07: 1, and other parts of Nigeria such as Zaria, Kaduna where male: female ratio is 5.8: 1 (Luga et al., 2017) and studies in other parts of the world (Daniel \& Bekoff, 1989; Cleaveland, 1996; Kongkaew et al., 2004; Ratsitorahina et al., 2007). The preference of female dogs over male dogs may be linked to the use of dogs for breeding purposes. Some individuals keep dogs as a source of income so that when they whelp, their puppies are sold. The high female population has both negative and positive impact in the control of rabies. The negative impact is that there is a high potential for large dog population in the nearest future thus, affecting rabies control programs. On another hand, it may be important in the reduction of spread of rabies through the reduction of aggression in males over a single female thereby reducing spread of rabies in dog population.

The incidence rate of dog bite cases was $27.04 \%$ among 159 respondents. Even though this figure appears low, one should still be worried if a single rabid dog bites a person without post exposure prophylaxis since this can be fatal resulting in loss of human life. Many deaths attributable to preventable diseases such as rabies have been recorded.

\section{CONCLUSION}

The results of this study indicated that a total of 257 dogs were counted in both Umuahia North and South LGAs Abia State. It also shows that there were more females compared to male dogs and the age structure tilted towards mature dogs (>1 year of age) than puppies. This study also shows low anti-rabies vaccination coverage in Umuahia North and Umuahia South LGAs and that vaccination level is below the recommended $70-80 \%$ vaccination coverage by the WHO. There also appears to be negligent dog ownership in Umuahia as many dog owners allowed their dogs to roam. This was majorly due to lack of awareness of the disease. Public education is needed especially in the rural areas, to inform the residents on the importance of vaccination of dogs against rabies. Various means of awareness of the disease could be employed which include electronic media, campaigns in print (posters) and general community participatory awareness programs.

\section{ACKNOWLEDGEMENTS}

We acknowledge the entire staff of Department of Veterinary Medicine, College of Veterinary medicine, Michael Okpara University of Agriculture, Umudike for their assistance during the course of the research.

\section{.REFERENCES}

Baker, J., Swanson, D., Tayman, J. \& Tedrow, L. (2017). Basic demographic concepts. 13(33). 10.1007/978-3 319-53745-0_2.

Cleaveland, S. (1996). The epidemiology of rabies and canine distemper in the Serengeti [Ph.D. Thesis]. University of London.

Cleaveland, S., Kaare, M., Knobel, D. \& Laurenson, M.K. (2006). Canine vaccination, providing broader benefits for disease control. Veterinary Microbiology, 117(1):43-50.

Daniels, T. J. \& Bekoff, M. (1989). Population and social biology of free-ranging dogs, Canisfamiliaris. Journal of Mammals, 70, 754-762.

FAO (2014). Dog population management. Report of the FAO/WSPA/IZSAM expert meeting - Banna, Italy, 14-19 March 2011. Animal Production Health Reproduction. No. 6. Food and Agricultural Organization, Rome.

Fekadu, M. (1991). Canine rabies. In Baer, G. M. (ed), The Natural History of Rabies (2nd edition, pp 367-387). Boca Raton: CRC Press.

Garba, A., Oyetunde, I.L., Kumbish, P.R., Clement, A.M., Chiko, K.L., Ahmed, J.S., Lapang, H., Dashe, Y., Tunde, O. \& Banyigyi, S.A. (2005). A retrospective study of biting dogs and rabies in Vom, Plateau State. Vom Journal of Veterinary Science, 1, 57-63.

Garba, A., Oboegbulem, S.I., Junaidu, A.U., Lombin, L.H., Makinde, A.A., Elsa, A.T. \& Ogunsan, A.E. (2006). Dog the principal reservoir host for rabies in Nigeria: current report. Book of abstracts of the $43^{\text {rd }}$ Annual. Congress of Nigeria Veterinary Medical Association held at Minna, Niger state $6^{\text {th }}-10^{\text {th }}$ November '2006.pp 22.

Hambolu, S.E., Dzikwi, A.A., Kwaga, J.K.P., Kazeem, H.M., Umoh, J.U. \& Hambolu, DA (2014). Dog ecology and population studies in Lagos State, Nigeria. Global Journal of Heath Science, 6.

Kongkaew, W., Coleman, P., Pfeiffer, D. U., Antarasena, C., \& Thiptara, A. (2004). Vaccination coverage and epidemiological parameters of the owned-dog population in Thungsong district, Thailand. Preview of Veterinary Medicine, 65, 105-115. http://dx.doi.org/10.1016/j.prevetmed.2004.05.009

Leeson, G.W. (2011). The importance of demography. Journal of Population Ageing, 4, 1-4.

Luga, I.I, Enemuneme, O.V. \& Apaa, T.T. (2017). Dog population and ecology in Ahmadu Bello university (ABU) main campus and Bomo village, Kaduna 
state, Nigeria. Sokoto Journal of Veterinary Science, 16(1), $54-59$.

National Population Census (2006). State population 2006. Nigeria data portal. https://nigeria.opendataforafrica.org/ifpbxbd/statepopulation-2006

Oboegbulem, S.O. (1994). Rabies in man and animal. 1st edition Fidelity Publishers Enugu-Nigeria. Pp1-23.

Oboegbulem, S. I. \& Nwakonobi, I. E. (1989). Population density and ecology of dogs in Nigeria: a pilot study. Review Science Technical Office International disease Epizootic, 8, 733-745.

Ogunkoya, A.B., Audu, S.W. \& Osinubi, M.O.V. (2012). Two fatal cases of rabies as a result of bites from apparently healthy dogs. Proceeding of World Rabies International, Global Ali Rabies Countries WEBINAR.

Otolorin, G.R, Umoh, J.U. and Dzikwi, A.A. (2014). Prevalence of rabies antigen in brain tissue of dogs slaughtered for human consumption and evaluation of vaccination of dogs against rabies in Aba, Abia State Nigeria. World Journal Public Health Science, 3: 5 .
Ratsitorahina, M., Rasambainarivo, J., Raharimanana, S., Rakotonandrasana, H., Andriamiarisoa, M., Rakalomanana, F. \& V Richard (2009). Dog ecology and demography in Antananarivo-2007. BMC Veterinary Research, 5, 21.

Tarsi, K. and Tuff, T. (2012). Introduction to population demographics. National Education Knowledge, 3(11), 3

World Health Organization (1980). Guidelines for dog rabies control. World Health Organization, Geneva.World Health Organization WHO, Report of WHO Consultation on Dog Ecology Studies Related to Rabies Control. W H O. Geneva.

World Health Organization (2004). WHO Expert

Consultation on Rabies: First report. WHO Technical Report Series 931. W H O, Geneva, Switzerland.

Article history:

Received: Jul 28, 2021,

Revised: August 13, 2021

Accepted: August15, 2021 